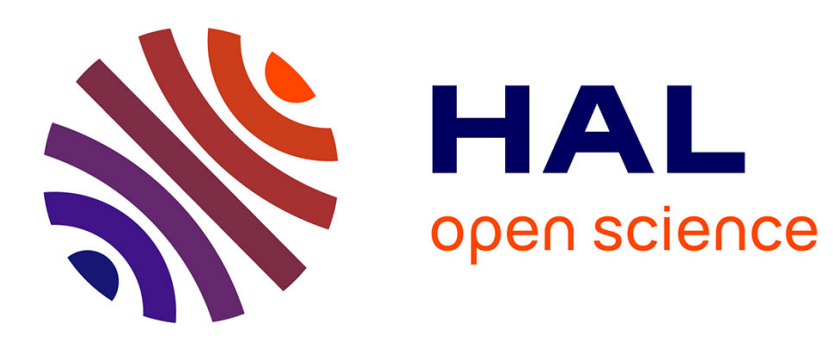

\title{
Epitaxial ferroelectric PZT and BST thin films by pulsed UV laser deposition
}

C. Champeaux, P. Marchet, A. Catherinot

\section{To cite this version:}

C. Champeaux, P. Marchet, A. Catherinot. Epitaxial ferroelectric PZT and BST thin films by pulsed UV laser deposition. Applied Surface Science, 1996, 96-98, pp.775 - 778. 10.1016/0169-4332(95)005536. hal-02296068

\section{HAL Id: hal-02296068 \\ https://hal-unilim.archives-ouvertes.fr/hal-02296068}

Submitted on 5 Jun 2020

HAL is a multi-disciplinary open access archive for the deposit and dissemination of scientific research documents, whether they are published or not. The documents may come from teaching and research institutions in France or abroad, or from public or private research centers.
L'archive ouverte pluridisciplinaire HAL, est destinée au dépôt et à la diffusion de documents scientifiques de niveau recherche, publiés ou non, émanant des établissements d'enseignement et de recherche français ou étrangers, des laboratoires publics ou privés. 
Applied Surface Science 96-98 (1996) 775-778

\title{
Epitaxial ferroelectric PZT and BST thin films by pulsed UV laser deposition
}

\author{
C. Champeaux, P. Marchet, A. Catherinot \\ Laboratoire de Matériaux Céramiques et Traitements de Surface - URA 320 CNRS, Université de Limoges, \\ 123, Av. Albert Thomas, 87060 Limoges Cedex, France
}

\begin{abstract}
Ferroelectric $\mathrm{PbZr}_{0.52} \mathrm{Ti}_{0.48} \mathrm{O}_{3}(\mathrm{PZT})$ and $\mathrm{Ba}_{0.65} \mathrm{Sr}_{0.35} \mathrm{TiO}_{3}(\mathrm{BST})$ thin films are prepared by laser ablation of sintered ceramic targets. The influence of the substrate temperature during deposition on the composition and the crystallographic structure is investigated for different substrates, in order to achieve an oriented or epitaxial growth.
\end{abstract}

\section{Introduction}

Ferroelectric materials are highly attractive with respect to non-volatile memories, dynamic random access memories and pyroelectric devices [1-3], because of their spontaneous polarization and high dielectric constant. So various thin ferroelectric films such as $\mathrm{BaTiO}_{3}, \mathrm{SrTiO}_{3}, \mathrm{PbTiO}_{3}$, etc., have been synthesized using different techniques including sol gel method [4], ion-beam sputtering [5], metal-organic decomposition [6] and pulsed laser deposition [7]. This latter method, 'famous' since its success in producing high quality thin films of high temperature superconductors, offers the ability to achieve highly oriented stoichiometric films at low substrate temperature in a high oxygen pressure. It can be applied to the deposition of ferroelectric materials of which many are multicomponent oxides having a perovskite-like structure, as superconductors have.

In this paper we describe our recent experiments to grow $\mathrm{PbZr}_{0.52} \mathrm{Ti}_{0.48} \mathrm{O}_{3}(\mathrm{PZT})$ and $\mathrm{Ba}_{0.65} \mathrm{Sr}_{0.35} \mathrm{TiO}_{3}$ (BST) thin films by pulsed laser ablation, under various conditions and the characterization of their composition and crystalline structure.

\section{Experimental procedure}

\subsection{Set-up}

Experiments are performed in an ultra high vacuum stainless-steel cell equipped with an introduction chamber for target and substrate manipulations. The stoichiometric sintered target of $\mathrm{PbZr}_{0.52} \mathrm{Ti}_{0.48} \mathrm{O}_{3}$ or $\mathrm{Ba}_{0.65} \mathrm{Sr}_{0.35} \mathrm{TiO}_{3}$, prepared by a conventional sintering process and having a density of $90 \%$ of the theoretical value, is mounted on a rotating system to ensure an uniform ablation rate. The beam of a pulsed excimer laser $(248 \mathrm{~nm}$ wavelength, pulse duration $14 \mathrm{~ns}$, repetition rate $10 \mathrm{~Hz}$, energy per pulse 20-300 $\mathrm{mJ}$ ), focused by a UV grade lens, is incident onto the target at an angle of $35^{\circ}$. The size of the elliptical laser spot on the target surface is typically $2.2 \mathrm{~mm}^{2}$. The vaporized material ejected normally to the target surface is deposited on a substrate placed opposite the target at about $4 \mathrm{~cm}$. The substrate can be heated up to about $800^{\circ} \mathrm{C}$ by an halogen lamp. Several gas inlets allow the control of the deposition and the cooling atmospheres.

\subsection{Deposition parameters}

According to the likeness of superconducting and ferroelectric materials (oxides with complex chemical composition and perovskite-like structure), working parameters are similar to those that we used for the realisation of high quality epitaxial $\mathrm{YBaCuO}$ superconducting thin films [8]. So the laser fluence on the target is $3 \mathrm{~J} / \mathrm{cm}^{2}$, the oxygen pressures are 0.3 mbar during deposition and 330 mbar during cooling. The films thickness, investigated by a surface profile measuring system, is typically $300-400 \mathrm{~nm}$ after ten minutes deposition.

\subsection{Film characterization}

The chemical composition of the films is determined by energy dispersive spectroscopy (EDS) and the structure is investigated by X-ray diffraction (XRD).

\section{PZT films on (100) MgO substrates}

Single-crystal $\mathrm{MgO}$ substrate is chosen because of the compatibility between its lattice parameter $(a=$ $4.21 \AA)$ and the PZT one $(a=4.036 \AA ; c=4.146 \AA)$.

\subsection{Composition}

Fig. 1 shows the evolution of the composition of films as a function of the deposition temperature. While the compositions of $\mathrm{Zr}$ and $\mathrm{Ti}$ remain constant close to the ideal ones (dotted lines on the figure), the one of $\mathrm{Pb}$ is 
strongly dependent of the deposition temperature. Above $600^{\circ} \mathrm{C}$ the $\mathrm{Pb}$ content of films decreases drastically and cancels at $790^{\circ} \mathrm{C}$ because of the volatility of this element and its oxides at elevated temperatures $[9,10]$.

\subsection{Structure}

XRD patterns of the films deposited in the temperature range $400-800^{\circ} \mathrm{C}$ are given on Fig. 2 . At low temperature $\left(400^{\circ} \mathrm{C}\right)$, the films are amorphous. The pyrochlore phase is present at $500^{\circ} \mathrm{C}$. The increase of the temperature leads to the vanishing $\left(\right.$ at $600^{\circ} \mathrm{C}$ ) of the pyrochlore phase on behalf of the perovskite one. A high degree of orientation is observed for perovskite phase, with (100) or (001) orientation. Above $700^{\circ} \mathrm{C}$, phases without $\mathrm{Pb}$, in agreement with composition study, take the place of the perovskite phase. These results indicate that in situ obtaining of PZT films with oriented perovskite structure is possible in the deposition temperature range $600-650^{\circ} \mathrm{C}$.

\subsection{PZT film on gold electrodes}

$100 \mathrm{~nm}$ thick bottom gold electrode is deposited on a $\mathrm{MgO}$ substrate using a sputtering technique. The PZT film is realized in the previous experimental conditions with an intermediate temperature $\left(630^{\circ} \mathrm{C}\right)$. X-ray diffraction (Fig. 3) measurements show mainly perovskite phase with a weak secondary phase which is not identified (only one peak). Unlike previous reports [9], perovskite phase remains (100) oriented, showing little influence of the metallic electrode. This result is very important because a high degree of orientation (up to epitaxy) is needed for good electrical properties.

\section{BST films}

\section{1. On (100) $\mathrm{SrTiO}_{3}$ substrates}

Concerning the BST (lattice parameter $3.97 \AA$ deposition, strontium titanate substrates (SrTiO, $a=3.9 \AA$ ) are chosen. A systematic study of the crystalline structure of the deposited films is undertaken in the range 500$700^{\circ} \mathrm{C}$. X-ray diffraction results are given on Fig. 4. At $500^{\circ} \mathrm{C}$, the films are amorphous. (100)-oriented BST phase grows from $600^{\circ} \mathrm{C}$. Lattice parameters, calculated from X-ray diffraction $(3.97 \AA)$, is significant of the $\mathrm{Ba}_{0.65} \mathrm{Sr}_{0.35} \mathrm{TiO}_{3}$ stoichiometry. So the transport of the species from the target to the substrate is congruent. The increase of the substrate temperature leads to a decrease of the width of the X-ray peaks, so, probably to an increase of the grain sizes.

\subsection{On Si substrates with metallic multilayers bottom electrodes}

For microelectonic applications (memories), silicon substrates are preferred. A few experiments are performed on different metallic electrodes ( $\mathrm{Au}, \mathrm{Pt}$, TiN, TiW... ). with the same deposition parameters. Unlike observations for PZT films, X-ray diffraction investigations reveal in all cases unoriented (polycristalline) BST perovskite phase. So, the orientation during deposition seems to depend strongly on substrate structure and interface phenomena.

\section{Conclusion}

PZT and BST films are prepared respectively on various substrates by laser ablation. The first experiments show a congruent transport of the species from the target to the substrate and an epitaxial growth on single-crystal substrates for a deposition temperature of $600^{\circ} \mathrm{C}$, when the other parameters are similar to those that we used for the deposition of epitaxial $\mathrm{YBaCuO}$ superconducting thin films (oxygen pressure $0.3 \mathrm{mbar}$, fluence $3 \mathrm{~J} / \mathrm{cm}^{2}$ ). These results prove that the deposition parameters seem to be approximatively the same for multicomponent oxides with perovskite-like structures. But the crystalline structure of films depends strongly on the substrate nature. The second step of this study will concern the deposition of PZT and BST materials on $\mathrm{YBaCuO} / \mathrm{MgO}$ substrates in order to characterize their electrical properties.

\section{References}

[1] R.E. Jones, P.D. Maniar, J.O. Olowolafe, A.C. Campbell and C.J. Mogab, Appl. Phys. Lett. 60 (1992) 1022.

[2] H. Adachi, Y. Mitsuya, O. Yamazaki and K. Wasa. J. Appl. Phys. 60 (1986) 736.

[3] T. Kawaguchi, H. Adachi, K. Setsune, O. Yamazaki and K. Wasa, Appl. Opt. 23 (1984) 2187.

[4] T. Tani, J.F. Li, D. Viehland and D.A. Payne, J. Appl. Phys. 75 (1994) 3017.

[5] I. Kanno, T. Kamada, S. Hayashi, M. Kitagawa and T. Hirao, Jpn. J. Appl. Phys. 32. Part 2 (1993) L950.

[6] W.L. Zhong, Y.G. Whang, D.S. Kong, P.L. Zhang and B.D. Qu, Thin Solid Films 237 (1994) 160.

[7] M. Okuyama, J.I. Asano, T. Imai, D.H. Lee and Y. Hamakawa, Jpn. J. Appl. Phys. 32, Part 1 (1993) 4107.

[8] C. Champeaux, P. Marchet, J. Aubreton, J.P. Mercurio and A. Catherinot, Appl. Surf. Sci. 69 (1993) 335.

[9] D. Roy and S.B. Krupanidhi, J. Mater. Res. 7 (1992) 2521.

[10] K.S. Grabowski, J.S. Horwitz and D.B. Chrisey, Ferroelectrics 116 (1991) 19. 


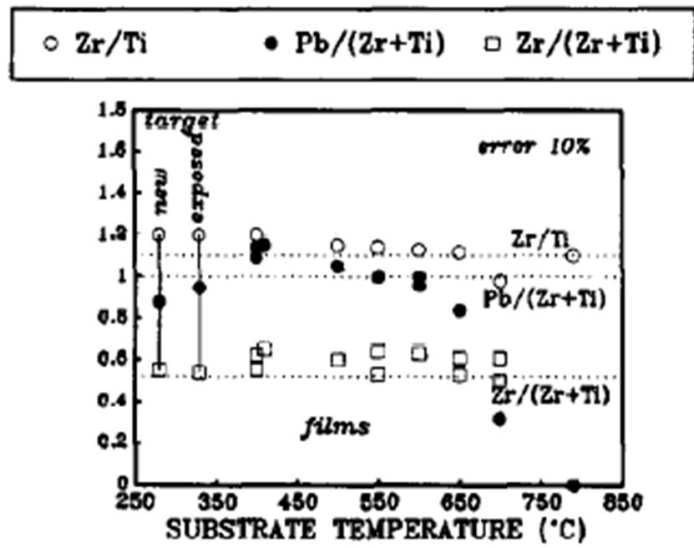

Fig. 1. PZT film composition versus deposition temperature (dotted lines correspond to the theoretical composition).

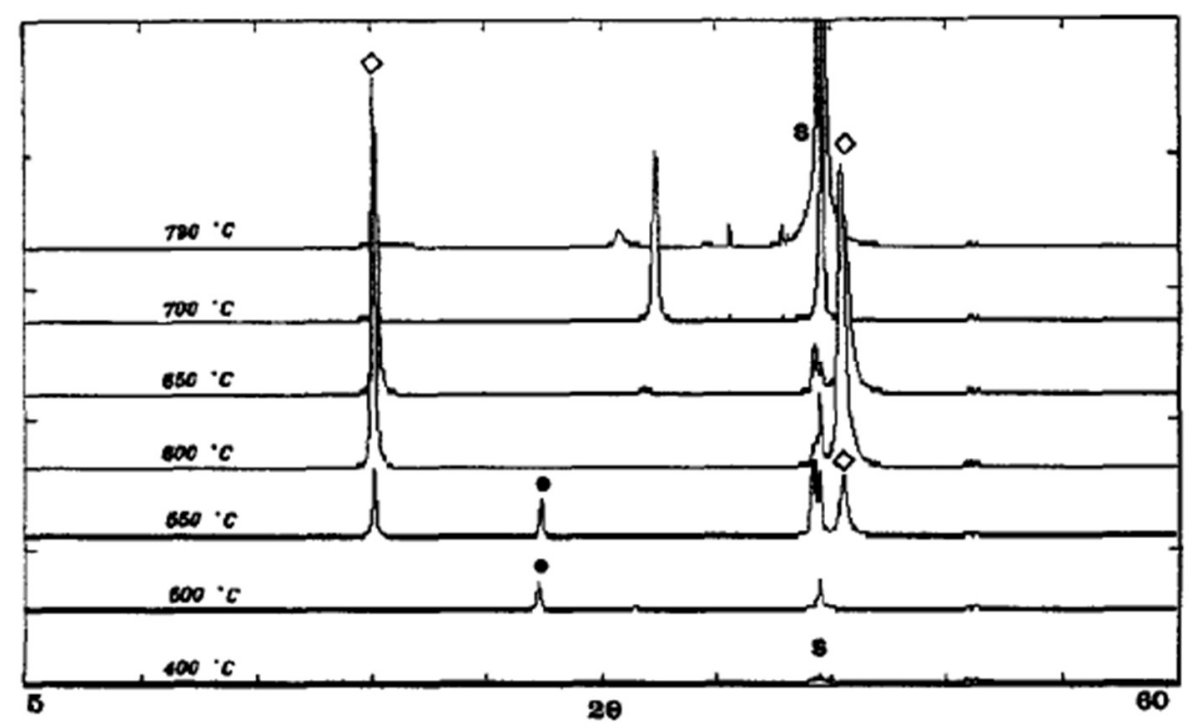

Fig. 2. X-ray diffraction patterns of PZT films on $\mathrm{MgO}$ substrates as a function of the deposition temperature $(\diamond:(100)$ oriented PZT perovskite, $\bullet$ : PZT pyrochlore, $\mathbf{S}$ : substrate).

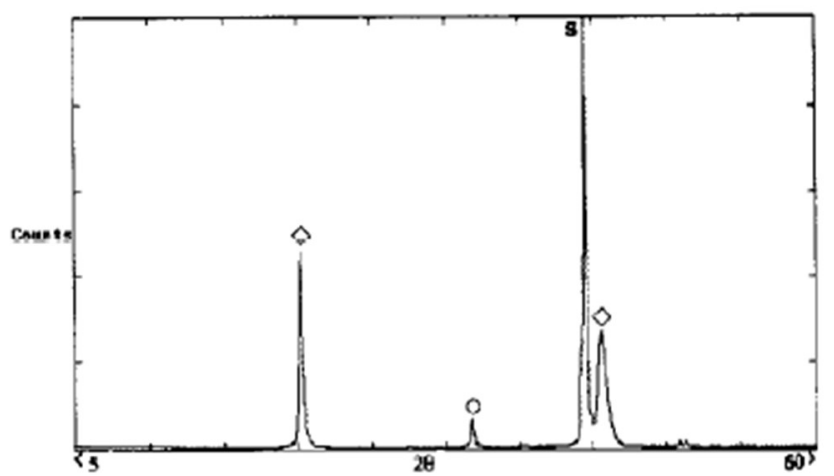

Fig. 3. X-ray diffraction patterns of PZT film on $\mathrm{Au} / \mathrm{MgO}$ substrate $(\diamond:(100)$ oriented PZT perovskite, $\bigcirc$ : unidentified secondary phase, $\mathbf{S}$ : substrate). 